\title{
1. OFFSCRAPING AND UNDERTHRUSTING OF SEDIMENT AT THE DEFORMATION FRONT OF THE BARBADOS RIDGE: AN INTRODUCTION TO THE DRILLING RESULTS OF LEG 78A AND EXPLANATORY NOTES ${ }^{1}$
}

\author{
J. C. Moore, Earth Sciences and Marine Studies, University of California at Santa Cruz \\ Bernard Biju-Duval, Institut Français du Pétrole \\ James H. Natland, Deep Sea Drilling Project \\ and \\ The Leg 78A Shipboard Scientific Party ${ }^{2}$
}

\section{INTRODUCTION}

This volume presents the initial scientific results of Deep Sea Drilling Project Leg 78A, which cored the seaward portions of the Lesser Antilles subduction complex on the eastern edge of the Barbados Ridge (Fig. 1). Leg $78 \mathrm{~A}$ was basically a drilling experiment to penetrate the toe of a particular type of accretionary complex at a convergent margin and reach materials whose eventual fate will either be subduction or underplating of the accretionary pile. The cores obtained document with considerable clarity the structure and style of deformation of the zone of active sediment accretion. A variety of downhole measurements provide important indications of the actual mechanics of faulting and deformation in the area.

In this chapter we present both the topical and regional background for the drilling, list the principal objectives for the drilling at each specific site, and provide the reader with general information necessary to understand the details of core-handling procedures, lithologic descriptions, and biostratigraphy. The volume itself is divided topically into groups of related chapters, beginning with the results of precruise and postcruise surveys and data syntheses, proceeding to site reports, then to chapters devoted specifically to studies in sedimentology, paleontology, downhole experiments, and so forth. The volume concludes with a summary chapter.

\section{TECTONIC PROCESSES AT CONVERGENT MARGINS}

The imbricate-thrust model (Beck, 1972; Seely et al., 1974; Karig, 1974; Karig and Sharman, 1975; and many others) provided a timely conceptualization of subduction-zone structure in the early to mid-1970s. This model has been used widely to interpret geophysical data from modern convergent margins as well as structural profiles

\footnotetext{
${ }^{1}$ Biju-Duval, B., Moore, J. C., et al., Init. Repts. DSDP, 78A: Washington (U.S. Govt. Printing Office).

2 Addresses: (Moore) Earth Sciences and Marine Studies, University of California at Santa Cruz, Santa Cruz, CA 95064; (Biju-Duval, present address) Centre National pour l'Exploitation des Ockans, 66 Avenue d'Iena, 75116 Paris, France; (Natland) Deep Sea Drilling Project, Scripps Institution of Oceanography, La Jolla, CA 92093; (Shipboard Scientific Party - see site reports for complete listing).
}

from supposed ancient equivalents. Critical tests of the imbricate-thrust concept have been made along the DSDP transects across Pacific subduction zones. Landward of the Middle America Trench off southern Mexico, drilling has indeed documented the progressive accretion of trench deposits much as predicted by the imbricatethrust model (Watkins, Moore, et al., 1982). However, southward along the same Trench, large-scale sediment subduction apparently is occurring simultaneously (von Huene, Aubouin et al., 1980). Tectonic scenarios, including combinations of sediment subduction, subduction erosion (Scholl et al., 1980), and accretion have been invoked to explain results of DSDP transects across convergent margins in the western Pacific (von Huene, Aubouin, et al., 1980; Hussong, Uyeda, et al., 1982). Clearly the diversity of tectonic regimes acting along modern convergent margins requires processes other than accretion and imbricate thrusting. A range of tectonic models is necessary to interpret new observations from both modern and ancient subduction complexes effectively. The factors causing certain convergent margins to be dominated by sediment subduction or by offscraping remain elusive and controversial.

Modern subduction zones constitute the best regions to test and develop tectonic models, because their setting is unequivocal. These regions are appropriately studied by combining geophysical surveys, surface sampling, high-resolution bathymetry, and drilling. Here we present drilling results from the Lesser Antilles subduction complex that provide further constraints to the range of models for convergent margins.

Because the language applicable to subduction zones is in constant flux, we define terms frequently used: "Accretion" refers in general to the transfer of material from the underthrusting to overriding plate. "Offscraping" describes accretion at the base of the trench slope (Scholl et al., 1980). "Underplating" designates a process of mass addition at depth beneath a rind of offscraped deposits (Watkins, McMillen, et al., 1982). "Subduction" describes the subcrustal descent of sediment or crust of the lower plate beneath the bedrock framework of a convergent margin (Scholl et al., 1980). Thus sediment may be "underthrust" beneath the toe of the trench slope to be either underplated at depth or ultimately subducted. 


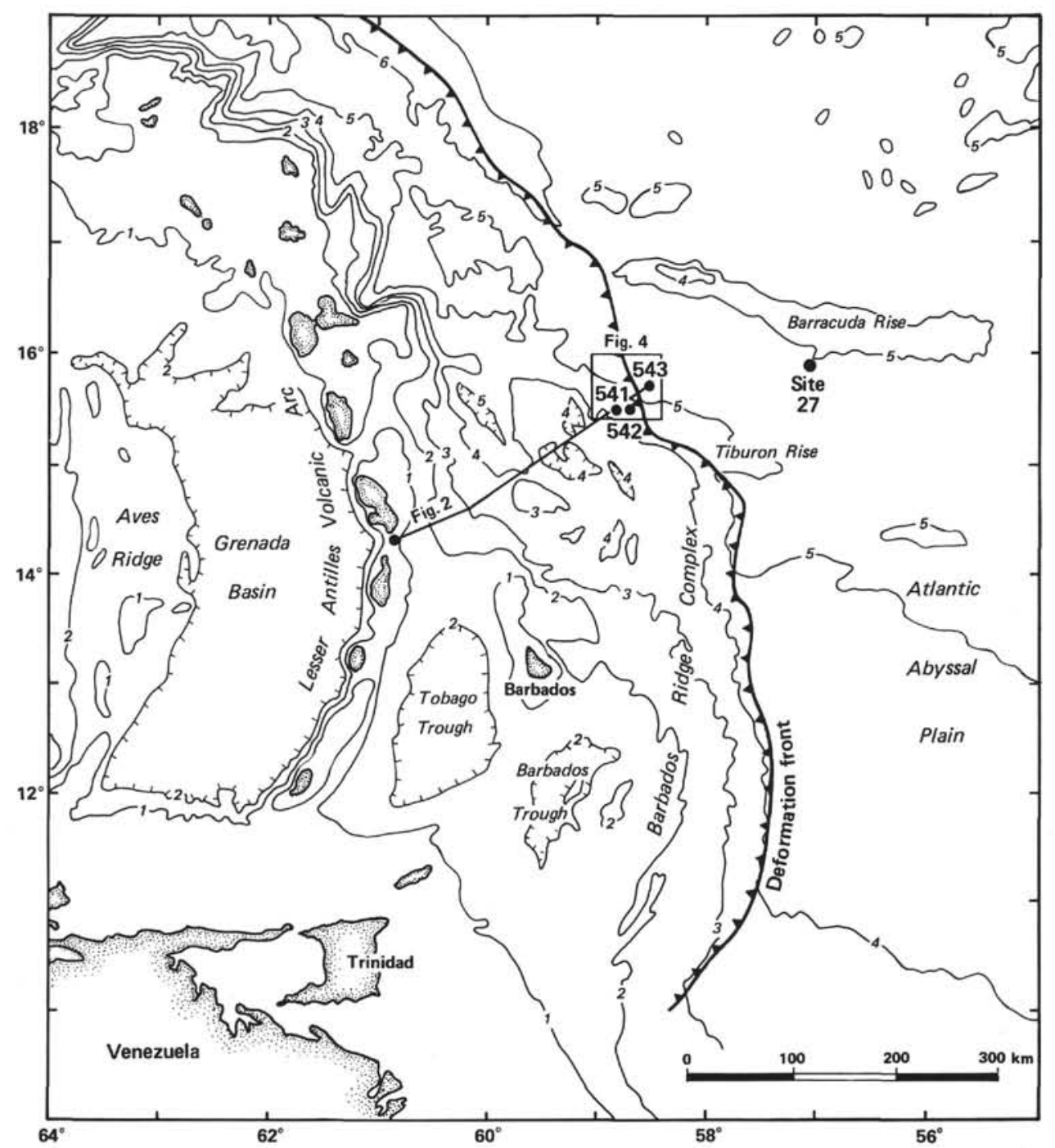

Figure 1. Regional location map. Note the position of the deformation front defining the eastward boundary of the Barbados Ridge complex and the Tiburon Rise underthrusting the deformation front near Sites 541, 542, and 543. Water-depth contours are in kilometers.

\section{REGIONAL BACKGROUND}

The Lesser Antilles intraoceanic arc is flanked on the west by the Grenada Basin, a possible back-arc basin (Biju-Duval et al., 1978), and to the east by Atlantic ocean crust (Fig. 1). The ocean crust underthrusts the arc at about $2 \mathrm{~cm} / \mathrm{yr}$. in a westerly direction (Minster and Jordan, 1978) and can be traced seismically to a depth of about $200 \mathrm{~km}$ (Tomblin, 1975). The forearc of the Lesser Antilles consists of the Barbados Ridge complex (Westbrook, 1982), a probable accretionary complex (Chase and Bunce, 1969; Marlow et al. 1974; Westbrook, 1975; Biju-Duval et al., 1978; Mascle et al., in press) and the Tobago and Barbados Troughs. The major forearc basin, the Tobago Trough, and its northward continuation, the Lesser Antilles Trough, contain more than $4 \mathrm{~km}$ of fill that become progressively more deformed to the east (Fig. 2; Biju-Duval et al., 1978). Very rapid subsidence and high accumulation rates have prevailed since at least the Pliocene. The Lesser Antilles volcanic arc is presently active with volcanic rocks as old as
Eocene. North of Dominica Island the arc splits into an Eocene-lower Miocene eastern arc capped with Oligocene and Miocene sedimentary deposits, and a post-Miocene western arc (Martin-Kaye, 1969). Outer Desirade Island east of Guadaloupe exhibits Mesozoic spilites and keratophyres that remain puzzling in the context of the regional geology (Mattinson et al., 1979).

The Lesser Antilles forearc narrows from more than $450 \mathrm{~km}$ in the south to less than $150 \mathrm{~km}$ in the north; the width in the vicinity of the Leg $78 \mathrm{~A}$ transect is about $260 \mathrm{~km}$ (Fig. 1). The seaward boundary of the forearc is marked not by a typical oceanic trench but a deformation front characterized by folding and thrust faulting (Chase and Bunce, 1969; Westbrook, 1975; Marlow et al., 1974; Peter and Westbrook, 1976; Biju-Duval et al., 1978; Mascle et al., in press). Large-scale folds and associated thrust faults define the deformation front to the east of the Island of Barbados (Mascle et al., in press; Biju-Duval et al., 1982). In the Leg 78A drilling area to the north, this structural boundary is characterized by a sediment wedge with discontinuous reflections; 


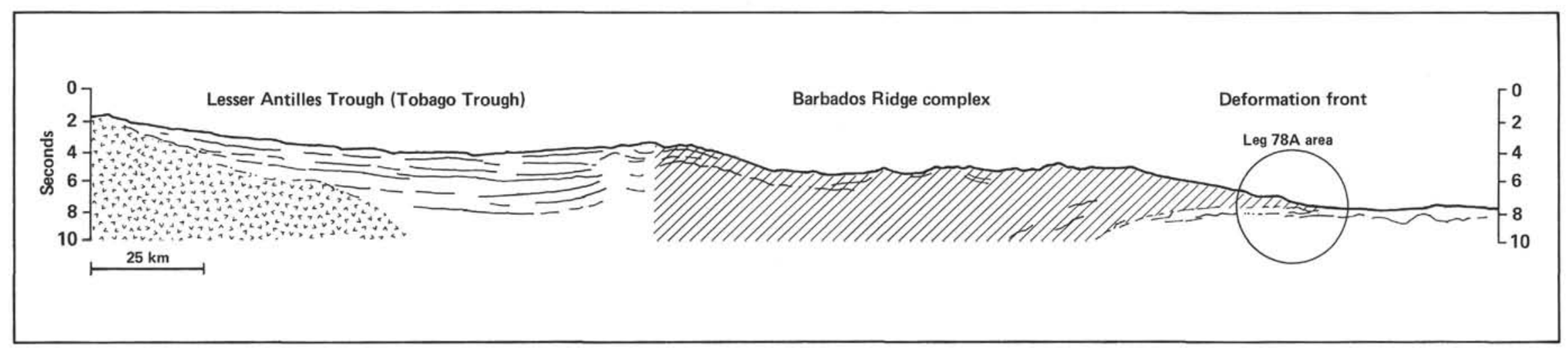

Figure 2. Cross section through the Barbados Ridge and Lesser Antilles Trough, interpreted from seismic reflection profiles. See Figure 1 for location. 
this wedge overlies an acoustically layered sequence that in turn overlies oceanic basement (Biju-Duval et al., 1978; Mascle et al., in press; Westbrook, 1982). The sediment wedge may be interpreted as a large gravity slide or, alternately, as offscrapings from the incoming ocean plate. The lack of resolved structure in the discontinuously reflective sediment wedge may be the result of masking by internal deformation and surface roughness on a smaller scale than that occurring to the south of the Leg $78 \mathrm{~A}$ area.

The sediment beneath the Atlantic Abyssal Plain at the deformation front of the Barbados Ridge complex ranges in thickness from more than $4 \mathrm{~km}$ in the south to about $700 \mathrm{~m}$ in the Leg 78A area (Mascle et al., in press). To the south the Cenozoic sedimentary detritus probably has been transported laterally from South America parallel to the deformation front of the Barbados Ridge complex (Saunders, 1980; Biju-Duval et al., 1978; Mascle et al., in press); the age of the oldest sediments could be pre-Late Cretaceous. To the north the oldest incoming sediment pile is probably Late Cretaceous. Both greater distance from the source and the damming effects of the Tiburon and Barracuda rises account for the decreasing sediment thickness to the north beneath the Atlantic Abyssal Plain. Prior accretion of thick sedimentary sections to the south may explain the broad forearc in this region (Westbrook, 1982).

On Barbados Island, highly deformed Paleogene terrigenous deposits are interpreted as a major gravity slide (Davies, 1971) or alternatively as offscraped strata of an earlier phase of accretion (Speed, in press). These terrigenous deposits are overlain structurally and possibly depositionally by Eocene to Miocene pelagic deposits that may have been accumulated on a trench slope (Pudsey and Reading, 1982; R.C. Speed, personal communication, 1982).

\section{TOPICAL CONTEXT OF LEG 78A}

Overall, the Barbados Ridge complex is characterized by a seaward-thinning, discontinuously reflective unit overlying a tabular acoustically layered unit (Figs. 2 and 3; Chase and Bunce, 1969; Westbrook et al., 1973; Marlow et al., 1974; Peter and Westbrook, 1976; Biju-Duval et al., 1978; Mascle et al., in press). One interpretation of this structural configuration suggests offscraping of the discontinuously reflective unit and selective underthrusting of the acoustically layered sequence. If in fact the sedimentary section is being partially scraped off and partially underthrust, then what controls this contrasting behavior? Superposition may be a factor; the upper layers of any incoming sediment section are more likely to be scraped off while the lower layers may be underthrust. The offscraping of trench fill at some subduction zones may be facilitated by décollement developed on subjacent weak hemipelagic muds accumulated on the outer slope (Karig, 1974). Similarly the diagenetically mature biogenic rocks at the base of the oceanic sediment column may show greater density and strength than the overlying hemipelagic and trench deposits; the stronger underlying section may actively resist offscraping and instead be subducted with the underlying oceanic crust (Moore, 1975). Understanding why sediment is accreted, underthrust, or ultimately subducted critically bears on problems such as the dominance of terrigenous deposits and paucity of pelagic rocks in supposed ancient subduction complexes (Scholl and Marlow, 1974).

As mentioned earlier, the deformation front of the Barbados Ridge complex shows a structural transition from large-scale folds and thrust faults in the south to a discontinuously reflective unit in the north near the Leg $78 \mathrm{~A}$ area. Changes in thickness, composition, and physical properties of the sediments (pelagic to hemipelagic

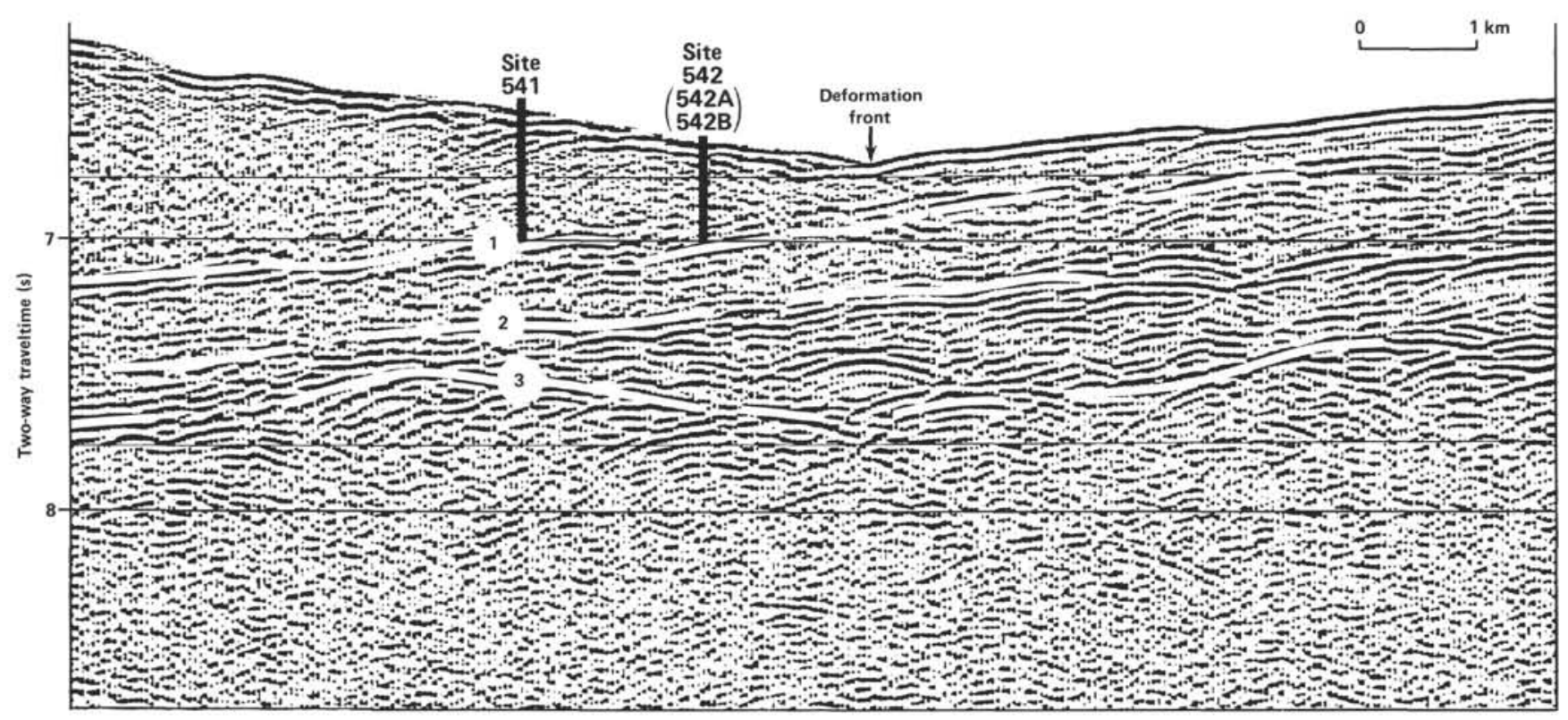

Figure 3. Seismic Reflection A1D, from Ngokwey et al., (this volume). Location is shown in Figure 4. 
to the north and terrigenous to the south) could explain this difference in structure (Mascle et al., in press; Westbrook, 1982). A prime goal of our drilling was to document the nature of the discontinuously reflective unit in order to compare it to rocks to the south and to test whether it was offscraped or slumped from higher on the slope. We also hoped to contrast differences in structural fabric, composition and physical properties that might account for the apparently contrasting behavior of the discontinuously reflective and layered units. The composition of the acoustically layered sequence is of particular interest as it may be subducted and become involved in island arc magma genesis.

\section{OPERATIONAL SUMMARY}

The principal goal of Leg 78A was to penetrate through the Barbados Ridge complex to the down-going ocean crust, an objective not yet achieved at any convergent margin. At Site 541, $3 \mathrm{~km}$ arcward of the deformation front (Figure 4), we hoped to penetrate $1 \mathrm{~km}$ of sediment reaching the ocean crust, but the hole collapsed at $460 \mathrm{~m}$ in an unstable zone between the discontinuously reflective and layered units. In another attempt to penetrate the top of the slope completely, we drilled two holes at Site 542 only $1.5 \mathrm{~km}$ arcward of the deformation front. Here the boundary between the discontinuously reflective and layered acoustic units occurs at about $300 \mathrm{~m}$ sub-bottom. Unfortunately, this contact, too, was unstable, leading to termination of drilling in Hole 542. In a final attempt to penetrate to the down-going ocean crust, we emplaced $60 \mathrm{~m}$ of drill-in casing across the unstable zone in Hole 542A. However, the casing failed to release from the drill string, precluding additional drilling. In this situation, though, a closed system through the casing and drill pipe was established, allowing us to make an inadvertent measurement of fluid pressure. Finally, at Site $543,3 \mathrm{~km}$ seaward of the deformation front, we sampled sediments seismically correlative to the acoustically layered unit. As such, our assemblage of six holes at three sites (Table 1) documents the nature of the incoming sediment and measures the structural deformation within the discontinuously reflective unit. The drilling results are presented in comprehensive form in the site reports, and are summarized in the synthesis at the end of this volume.

\section{AUTHORSHIP OF SITE REPORTS}

Although the site reports are collectively authored, various shipboard scientists consistently wrote specific sections. Co-Chiefs Bernard Biju-Duval and Casey Moore were responsible for Site data, principal results, and background and objectives. Glenn Foss, our Cruise Operations Manager, wrote the sections on operations. Audrey Wright, with the assistance of Carol Pudsey, Chris Hemleben, Marc Tardy, and Jim Natland, wrote the sections on sediment lithology; within these sections, Carol Pudsey specifically took responsibility for the portions dealing with X-ray diffraction and bioturbation, and Jim Natland the portions dealing with volcanic ash. Sections on structural geology were written by Darrel Cowan. Barrel sheets were prepared by Jim Natland. In the biostratigraphy sections, Jim Bergen wrote the portions dealing with nannofossils, Nona Renz the portions on radiolarians, and Rudi Guerra and Chris Hemleben the

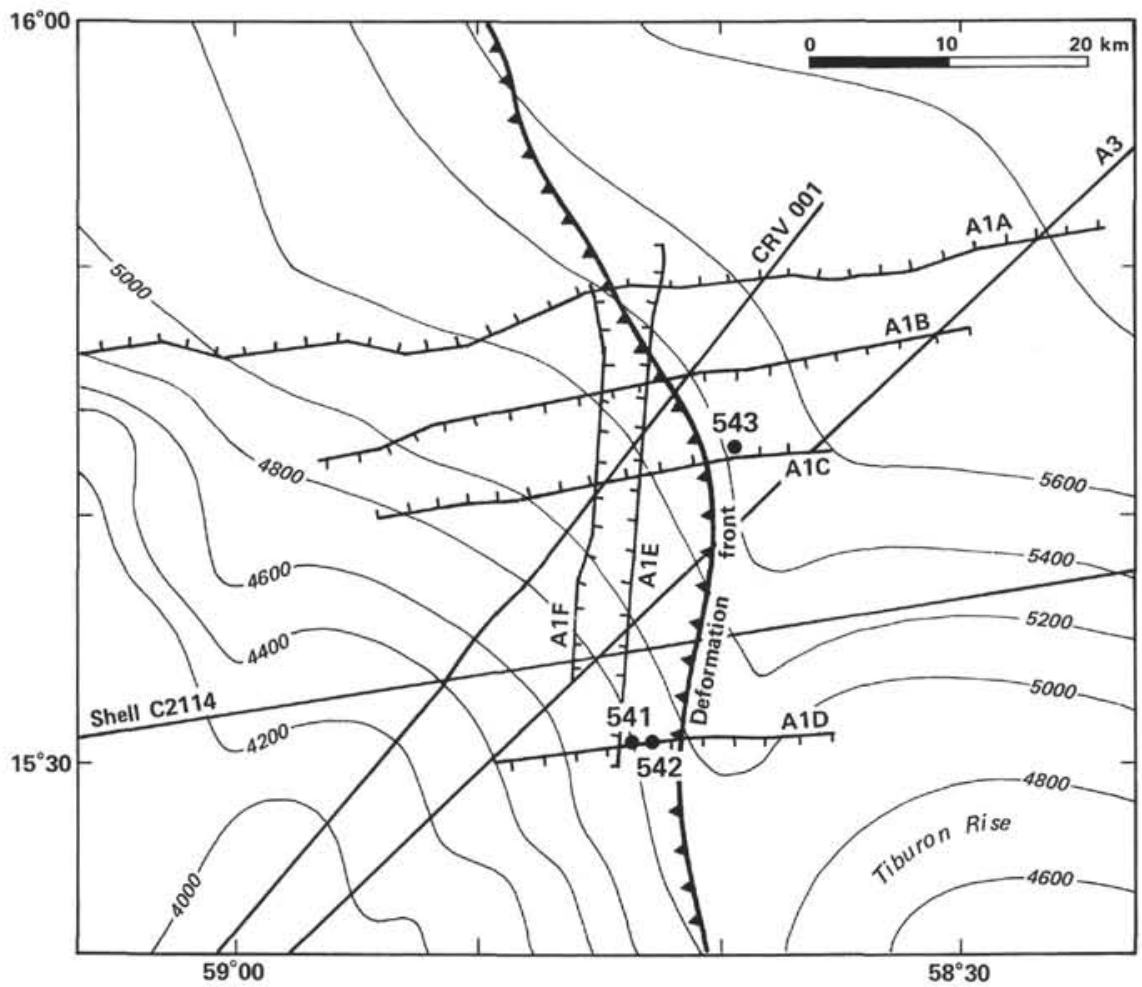

Figure 4. Detailed site location map. Note the position of the deformation front and the location of seismic reflections obtained for the site survey. 
Table 1. Leg 78A coring summary.

\begin{tabular}{lccccccccc}
\hline & $\begin{array}{c}\text { Dates } \\
(1981)\end{array}$ & Latitude & Longitude & $\begin{array}{c}\text { Water } \\
\text { depth } \\
(\mathrm{m})\end{array}$ & $\begin{array}{c}\text { Penetration } \\
(\mathrm{m})\end{array}$ & $\begin{array}{c}\text { No. of } \\
\text { cores }\end{array}$ & $\begin{array}{c}\text { Meters } \\
\text { cored }\end{array}$ & $\begin{array}{c}\text { Meters } \\
\text { recovered }\end{array}$ & $\begin{array}{c}\text { Recovery } \\
(\%)\end{array}$ \\
\hline 541 & $13-21$ February & $15^{\circ} 31.201^{\prime} \mathrm{N}$ & $58^{\circ} 43.663^{\prime} \mathrm{W}$ & 4940 & 459 & 50 & 459.0 & 400.8 & 87.3 \\
542 & $21-22$ February & $15^{\circ} 31.184^{\prime} \mathrm{N}$ & $58^{\circ} 42.787^{\prime} \mathrm{W}$ & 5016 & 240 & 7 & 66.50 & 52.6 & 79.3 \\
$542 \mathrm{~A}$ & $22-23$ February & $15^{\circ} 31,174^{\prime} \mathrm{N}$ & $58^{\circ} 42.802^{\prime} \mathrm{W}$ & 5016 & 325.5 & 12 & 114.0 & 90.0 & 79.1 \\
$542 \mathrm{~B}$ & $24-27$ February & $15^{\circ} 31.198^{\prime} \mathrm{N}$ & $58^{\circ} 42.793^{\prime} \mathrm{W}$ & 5016 & 323.5 & 0 & 0 & 0 & 0 \\
543 & 28 Feb-3 March & $15^{\circ} 42.726^{\prime} \mathrm{N}$ & $58^{\circ} 39.243^{\prime} \mathrm{W}$ & 5633 & 332 & 34 & 324.0 & 228.4 & 70.5 \\
$543 \mathrm{~A}$ & 3-9 March & $15^{\circ} 42.738^{\prime} \mathrm{N}$ & $58^{\circ} 39.216^{\prime} \mathrm{W}$ & 5633 & 455 & 16 & 142.5 & 69.4 & 48.7 \\
\hline a Calculated from sea level. & & & & & & & &
\end{tabular}

portions on foraminifers. Chris Hemleben wrote the sections on paleoenvironment. Jim Natland and George Claypool wrote the sections on pore-fluid chemistry and organic chemistry, respectively. Mike Marlow wrote the sections on physical properties procedures and results. Doug Wilson wrote the sections on paleomagnetics, and Dan Davis the section on temperature measurements in the Site 543 report. Bernard Biju-Duval and Mike Marlow wrote the sections on seismic stratigraphy. Casey Moore and Bernard Biju-Duval wrote the concluding summary and conclusions sections.

Final drafts of the site reports were prepared at the post-cruise meeting, and the results therein may have been superceded by subsequent work reported in the specialty chapters of this volume.

\section{EXPLANATORY NOTES}

\section{Introduction}

The following information is presented to aid investigators in selecting samples for detailed study and in understanding the (1) terminology, labeling, and numbering conventions used by the Deep Sea Drilling Project; (2) sediment classification and biostratigraphic framework; and (3) how preliminary lithologic and paleontologic data are presented on core forms, so that sampling can be guided. Potential investigators who desire to obtain samples should refer to the DSDP-NSF Sample Distribution Policy (in this volume). Sample request forms may be obtained from: The Curator, Deep Sea Drilling Project, A-031, University of California, San Diego, La Jolla, California 92093. Requests must be as specific as possible: include site, core, section, interval within a section, and volume of sample required.

\section{Numbering of Sites, Holes, Cores, and Samples}

DSDP drill sites are numbered consecutively from the first site drilled by Glomar Challenger in 1968. Site numbers are different from hole numbers: a site number refers to one or more holes drilled while the ship was positioned over one acoustic beacon. These holes could be located within a radius as great as $900 \mathrm{~m}$ from the beacon. Several holes may be drilled at a single site by pulling the drill pipe above the seafloor (out of one hole), and moving the ship $100 \mathrm{~m}$ or more from the previous hole, and then drilling another hole.

The first (or only) hole drilled at a site takes the site number. A letter suffix distinguishes each additional hole at the same site. For example: the first hole takes only the site number; the second takes the site number with suffix A; the third takes the site number with suffix B, and so forth. It is important, for sampling purposes, to distinguish the holes drilled at a site because recovered sediments or rocks from different holes usually do not come from equivalent positions in the stratigraphic column.

There are two types of coring systems used on the Glomar Challenger: (1) the standard DSDP rotary-coring system, which cuts $\sim 9.5$-m-long cores and has been used since Leg 1; and (2) the Hydraulic Piston Coring (HPC) system, used since Leg 64. Only the standard rotary coring system was used during Leg 78A.

The cored interval is measured in meters below the seafloor. The depth interval of an individual core is the depth below seafloor that the coring operation began to the depth that the coring operation ended. For example, in the rotary-coring system, each coring interval is generally $9.5 \mathrm{~m}$ long, which is the nominal length of a core barrel; however, the coring interval may be shorter or longer (rare). "Cored intervals" are not necessarily adjacent to each other, but may be separated by "drilled intervals." In soft sediment, the drill string can be "washed ahead" with the core barrel in place, but not recovering sediment, by pumping water down the pipe at high pressure to wash the sediment out of the way of the bit and up the space between the drill pipe and wall of the hole; however, if thin hard rock layers are present, then it is possible to get "spotty" sampling of these resistant layers within the washed interval, and thus have a cored interval greater than $9.5 \mathrm{~m}$. In drilling hard rock, a center bit may replace the core barrel if it is necessary to drill without core recovery.

Cores taken from a hole are numbered serially from the top of the hole downward. Core numbers and their associated cored interval in meters below the seafloor are normally unique for a hole; however, problems may arise if an interval is cored twice. When this situation occurs, the core number is assigned a suffix, such as "S" 3 for supplementary. In the rotary-coring system, full recovery for a single core is normally $9.28 \mathrm{~m}$ of sediment or rock, which is in a plastic liner (6.6 cm I.D.) plus about a 0.2 -m-long sample (without a plastic liner) in the core catcher. The core catcher is a device at the bottom of the core barrel that prevents the cored sample from sliding out when the barrel is being retrieved from the hole. The sediment core, which is in the plastic liner,

\footnotetext{
${ }^{3}$ Note that this designation has been used on previous legs as a prefix to the core number for side-wall core samples.
} 
is then cut into 1.5 -m-long sections and numbered serially from the top of the sediment core (Fig. 5). When we obtain full recovery, the sections are numbered from 1 through 7 , with the last section possibly being shorter than $1.5 \mathrm{~m}$. The core catcher sample is placed below the last section when the core is described, and labeled core catcher (CC): it is treated as a separate section.

When recovery is less than $100 \%$, and if the sediment or rock is contiguous, the recovered sediment is placed in the top of the cored interval, and then 1.5-m-long sections are numbered serially, starting with Section 1 at the top. There will be as many sections as are needed to accommodate the length of the core recovered (Fig. 5); for example, $3 \mathrm{~m}$ of core sample in plastic liners will be divided into two 1.5-m-long sections. Sections are cut starting at the top of the recovered sediment, and the last section may be shorter than the normal $1.5 \mathrm{~m}$ length.

This technique differs from the labeling systems used on Legs 1 through 45 , which had a designation called "zero section." On Legs 1-45 there were seven sections labeled $0,1,2,3,4,5$, and 6 . In the new system used from Leg 46 to the present there are seven sections labeled $1,2,3,4,5,6$, and 7 .

When recovery is less than $100 \%$, the sediment's original stratigraphic position in the cored interval is unknown, so we employ the convention assigning the top of the sediment recovered to the top of the cored interval. This is done for convenience in data handling and consistency. If recovery is less than $100 \%$, and core fragments are separated, and if shipboard scientists believe
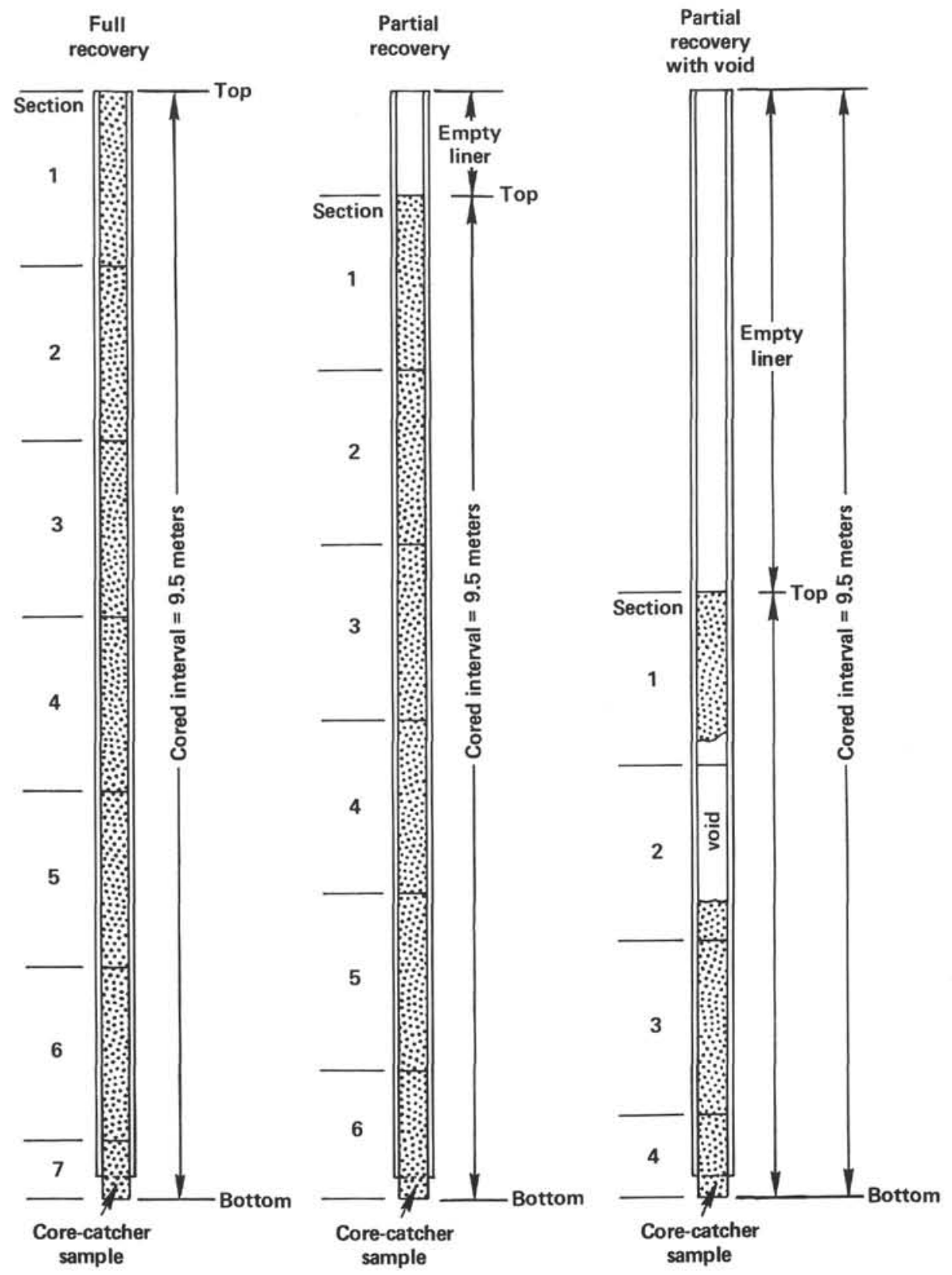

Figure 5. Diagram showing procedure in cutting and labeling of core sections. 
the sediment was not contiguous, then sections are numbered serially and the intervening sections are noted as void, whether it is contiguous or not. The core-catcher sample is described in the visual core descriptions beneath the lowest section.

Samples are designated by centimeter distances from the top of each section to the top and bottom of the sample in that section. A full identification number for a sample consists of the following information: leg-holecore number-section, interval in centimeters from the top of section. For example, a sample identification number of 78A-543A-6-3, 12-14 cm is interpreted as follows: $12-14 \mathrm{~cm}$ designates a sample taken at 12 to $14 \mathrm{~cm}$ from the top of Section 3 of Core 6, from the second hole drilled at Site 543 during Leg 78A. A sample from the core-catcher of this core is designated as $78 \mathrm{~A}-543 \mathrm{~A}$ 6 ,CC (12-14 cm).

The depth below the seafloor for a sample numbered at "78A-543A-6-3, 12-14 cm is the summation of the following: (1) the depth to the top of the cored interval for Core 6, which is $370 \mathrm{~m}$; (2) plus $3 \mathrm{~m}$ for Sections 1 and 2 (each $1.5 \mathrm{~m}$ long); plus the $12 \mathrm{~cm}$ depth below the top of Section 3. All of these variables add up to $373.21 \mathrm{~m}^{4}$, which by convention is the sample depth below the seafloor.

\section{Handling of Cores Containing Sediments}

A core is normally cut into $1.5-\mathrm{m}$ sections, sealed, and labeled; and then the sections are brought into the core laboratory for processing. The following determinations are normally made before the sections are split: gas analysis and continuous wet-bulk density determinations using the Gamma Ray Attenuation Porosity Evaluation (GRAPE) as described in Boyce (1976).

The cores are then split longitudinally into "work" and "archive" halves. Samples are extracted from the "work" half, including those for determination of grainsize distribution, mineralogy by X-ray diffraction, sonic velocity by the Hamilton Frame method as described in Boyce (1976), wet-bulk density by a static GRAPE technique (Boyce, 1976), water content by gravimetric analysis, carbon-carbonate analysis, percent calcium carbonate (carbonate bomb), geochemical analysis, paleontologic studies, and others.

Smear slides or thin sections from each major lithology, and most minor lithologies, are prepared and examined microscopically. The archive half is then described and photographed. Physical disturbance by the drill bit, color, texture (for uncemented lithologies), and sedimentary and igneous structures and composition $( \pm 20 \%)$ of the various lithologies are noted on standard core description sheets (Fig. 6).

After the cores are sampled and described, they are maintained in cold storage aboard Glomar Challenger until they can be transferred to the DSDP repository. Core sections that are removed for organic geochemistry study are frozen immediately on board ship and kept fro-

\footnotetext{
${ }^{4}$ Sample requests should refer to a specific interval within a core-section, rather than the level below seafloor.
}

zen. Frozen cores are presently stored at the DSDP West Coast Repository (Scripps Institution of Oceanography).

These core descriptions, smear-slide descriptions (plus occasional peels and thin sections), and carbonate-bomb $\left(\% \mathrm{CaCO}_{3}\right)$ determinations (all of these data are determined aboard ship) serve as the data for the visual core descriptions presented here. These samples, and their location in the core, are coded with a symbol on the core description sheets. The keys to these codes, in order to identify the samples, are shown in Figures 6-10.

\section{Special Cores and Samples}

Occasionally, special cores or samples are recovered that require specific identification. These are designated as follows:

$\mathrm{X}=$ miscellaneous debris or out-of-sequence core material

C $=$ center bit samples (i.e., samples obtained upon removal of the center bit-a device to prevent core recovery while drilling or washing ahead for some interval)

$\mathrm{S}$ = side-wall core (i.e., a core taken in the side of the hole, usually to obtain a sample of material not recovered during previous coring)

$\mathrm{H}=\mathrm{a}$ wash core (i.e., a core taken while washing ahead for an interval larger than $9.5 \mathrm{~m}$-say, $50 \mathrm{~m}$-but without the center bit in place; such a core may sample at several places in the washed interval, but their depths cannot be specified within that interval)

B = bit material (i.e., material removed from core bits upon retrieval of the drill string following completion of a hole, or prior to reentry with a new core bit)

Cores or samples of these types are designated X1, $\mathrm{X} 2, \mathrm{H} 1, \mathrm{H} 2$, and so on, each type in the sequence they were obtained. Additional types of special samples may be designated by the shipboard party or cruise operations manager. The letter designation for these samples is chosen in consultation with the DSDP curatorial representative and laboratory officer, and is indicated on each core description form.

\section{Classification of Sediments}

Several lithologic classifications designed for the construction of the several graphic core and hole summaries have been used during the lifetime of the Deep Sea Drilling Project. The classification system described here was devised by the JOIDES Panel on Sedimentary Petrology and Physical Properties and adopted for use by the JOIDES Planning Committee in March 1974.

\section{Principles Used in Classification}

This is a lithologic summary classification designed to generalize core descriptive material of greater detail into a form suitable for standard core and hole logs. Its systematic use will facilitate core to core and leg to leg comparisons.

The classification covers most of the lithologic types encountered so far but does not attempt to be compre- 


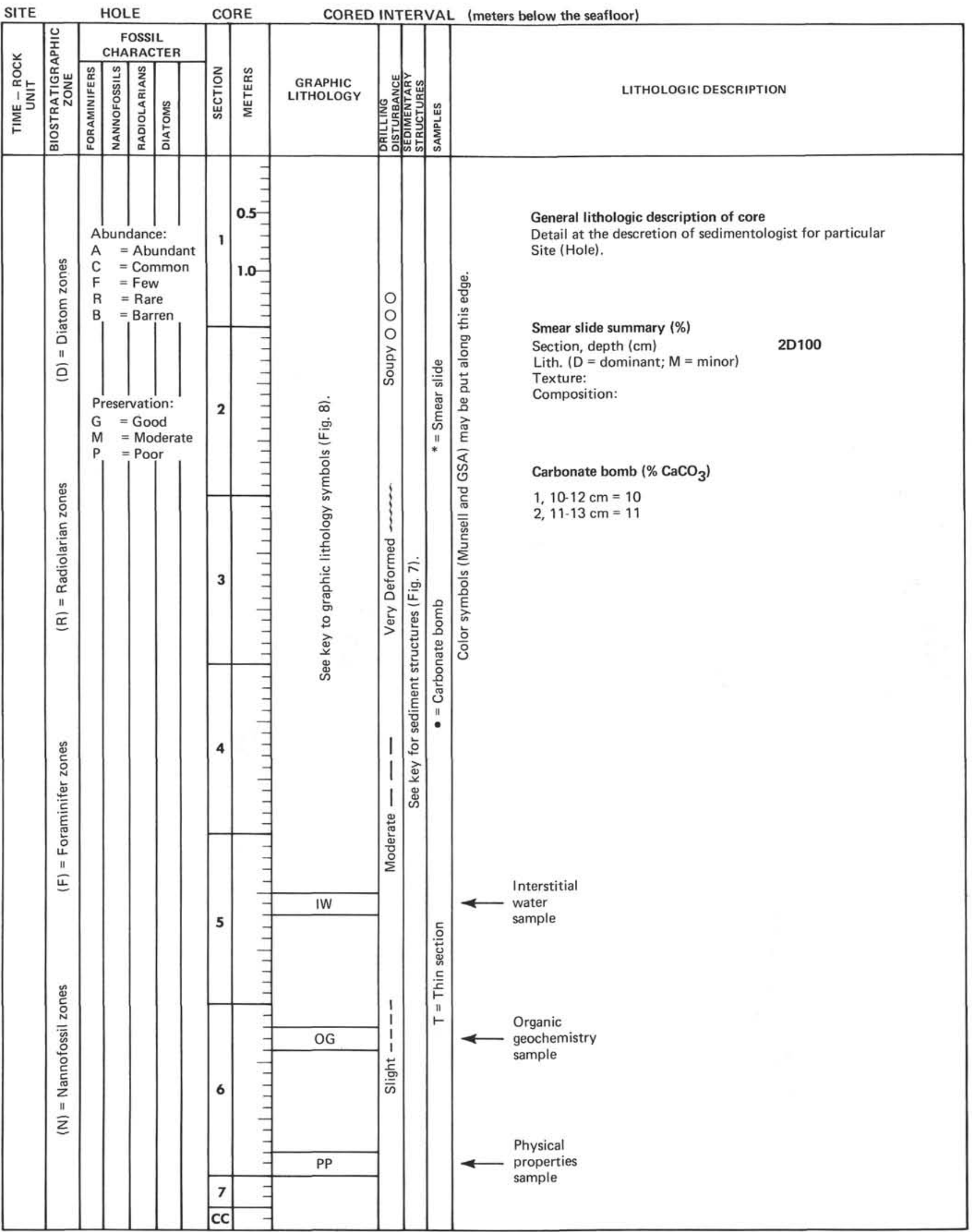

Figure 6. A typical sediment core description sheet, with the sediment deformation symbols, sample codes, and other general information. 
hensive. A category "Special Rock Types" shows additional definitions and terminology at the discretion of the shipboard staff for rock types not covered.

Sediment names are those in common usage and have been defined within the limits of existing definitions.

Categories are based on sediment parameters measured on board ship. Refinement by shore laboratory data is possible but not necessary.

The classification is descriptive, genetic implications are not intended.

The degree of detail of the classification is scaled to the space limitations of printed graphic hole and core summaries.

\section{Shipboard Parameters Measured}

Sediment and rock names are defined solely on the basis of compositional and textural parameters. The compositional factors are most important for description of those deposits more characteristic of open-marine conditions, with textural factors becoming more important for the classification of hemipelagic and near-shore facies. Sediment names are thus based solely upon these parameters as determined in smear slides aided by compositional and textural properties apparent to the naked eye or under the hand lens. Other descriptive parameters include: induration, sediment disturbance, sedimentary structures, and color. The determination of these parameters is as follows:

I. Composition. Biogenic and mineral components are estimated in percent from smear slides. $\mathrm{CaCO}_{3}$ content is estimated by using the carbonate bomb available on the ship. Even with rapid use, a value to $\pm 5 \%$ is achievable.

II. Texture. Visual estimates are made from smearslide examination.

III. Induration. The determination of induration is highly subjective, but field geologists have successfully made similar distinctions for many years. The categories suggested here are thought to be practical and significant. The criteria of Moberly and Heath (1971) are used for calcareous deposits; subjective estimate or behavior in core cutting for others. There are three classes for calcareous sediments; two for all others.

A. Calcareous sediments

1. Soft: oozes have little strength and are readily deformed under the finger or the broad blade of a spatula

2. Firm: chalks are partly indurated oozes: they are friable limestones that are readily deformed under the fingernail or the edge of a spatula blade. More indurated chalks are termed limestones (see the text that follows).

3. Hard: limestones as a term should be restricted to cemented rocks.

B. The following criteria are recommended for all but calcareous sediments:

1. If the material is in a low state of induration as to allow the core to be split with a wire cutter, the sediment name only is used (e.g., silty clay $=$ mud).

2. If the core must be cut on the band saw or diamond saw, the suffix "stone" is used (e.g., silty claystone $=$ mudstone, or shale, if fissile.)

IV. Sediment Disturbance. Deformational structures are generally of the type found in piston cores, and are usually simple to visualize and interpret. A. Soft to firm sediment. The following categories are recommended:

1. Slightly deformed-bedding contacts are slightly bent.

2. Moderately deformed-bedding contacts have undergone extreme bowing.

3 . Very deformed-bedding is completely disturbed, sometimes showing symmetrical diapirlike structure.

4. Soupy-water-saturated intervals have lost all aspects of original bedding.

B. Hard sediments. There is also the need to indicate the degree of fracturing in hard sediments-rock, best accomplished with a written description in the Lithologic Description portion of the Core Description Sheet (Fig. 6).

C. Drilling "biscuits." Semi-indurated sediments are broken into flat 3 to $5 \mathrm{~cm}$ or so "biscuits," which internally are undeformed, but were rotated against each other resulting in lenses of soft, intensely deformed mud or ooze in between. Description is also best accomplished using the Lithologic Description portion of the Core Description Sheet (Fig. 6).

V. Sedimentary structures. In many cores it is extremely difficult to differentiate between natural and coring-induced structures. Consequently, the description of sedimentary structures is optional. The following approach is suggested as a guideline, but the specialist is encouraged to use his own preferred system and set of symbols.

A. Median grain-size profile. For the sections of terrigenous sediments, with interbeds of varying textural characteristics, the construction of a median grain-size profile based on handlens observations provides a rapid method for illustrating graded and nongraded beds, bed thickness, and size distribution.

B. Sedimentary structures. A set of suggested symbols is provided for categories shown on Figure 7.

VI. Color. Colors are assigned according to standard Munsell and GSA color charts.

\section{Use of the Core Form}

Mandatory Graphic Lithology column. This graphic column is based on the classification scheme just described. Completion of the column using the appropriate symbols (Fig. 8) is done for each site, and is included in the Initial Core Description (ICD) and Initial Reports 


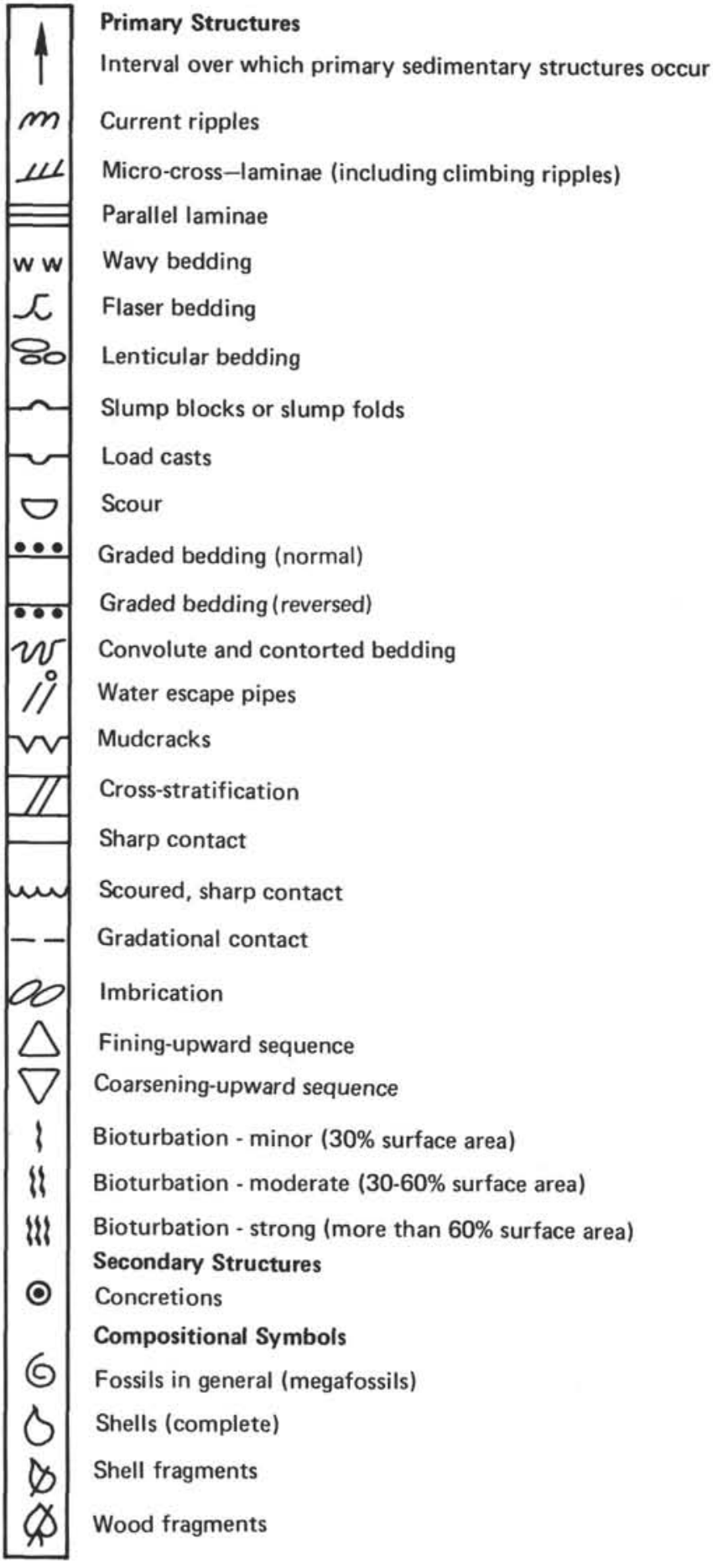

Figure 7. Structure symbol code for sediments.

volume. The "Special Rock Type" category is used for sediment types not in the classification.

Drilling Disturbance column. The drilling disturbance column is always completed using symbols and distinctions to be discussed later.

Sedimentary Structure Column. Structures may be designated on the core form in the sedimentary structure column parallel to the sediment disturbance column, and/ or on the median grain-size profile (for the sections of terrigenous sediments, with interbeds of varying textural characteristics). The median grain-size profile is located in the lithologic description portion of the core form. A set of suggested symbols for a few more common structures has been prepared by DSDP (Fig. 8), but the shipboard geologist may use whatever additional symbols are necessary. These optional columns do not substitute for the mandatory sediment disturbance column and are distinct from it.

Lithologic Description column. Format, style, and terminology of the descriptive portion of the core sheets are not controlled by the mandatory column scheme, beyond the minimal name assignment, which should be derived from the classification. However, colors and additional information on structure and textures are normally included in the textural section of the core description.

\section{Lithologic Classification Scheme}

The following define compositional class boundaries and the use of qualifiers in the lithologic classification scheme:

$\mathrm{CaCO}_{3}$ content (determined by $\mathrm{CaCO}_{3}$ bomb): $30 \%$ and $60 \%$. With a $5 \%$ precision and given the natural frequency distribution of $\mathrm{CaCO}_{3}$ contents in oceanic sediments, these boundaries can be reasonably ascertained.

Biogenic opal abundance (expressed as percent siliceous skeletal remains in smear slides): $10 \%, 30 \%$, and $50 \%$. Smear-slide estimates of identifiable siliceous skeletal material generally imply a significantly higher total opal abundance. The boundaries have been set to take this into account.

Abundance of authigenic components (zeolites, $\mathrm{Fe}$ and $\mathrm{Mn}$ micronodules, etc.), fish bones, and other indicators of very slow sedimentation (estimated in smear slides; semiquantitative boundary): common $10 \%$. These components are quite conspicuous, and a semiquantitative estimate is adequate. Even a minor influx of calcareous, siliceous, or terrigenous material will, because of the large difference in sedimentation rate, dilute them to insignificance.

Abundance of terrigenous detrital material (estimated from smear slides): $30 \%$

Qualifiers: numerous qualifiers are suggested; the options are used freely. However, components of less than $5 \%$ (in smear slide) are not used as qualifiers except in special cases. The most important component is the last qualifier. No more than two qualifiers are used.

\section{Description of Sediment Types}

I. Pelagic clay. Principally authigenic pelagic deposits accumulate at very slow rates. The class is often termed brown clay or red clay, but because these terms are confusing, they are not recommended.

A. Boundary with terrigenous sediments: where authigenic components (Fe-Mn micronodules, zeolites), fish debris, and so on become common in smear slides. Note: Because of large discrepancy in accumulation rates, transitional deposits are exceptional. 
J. C. MOORE, B. BIJU-DUVAL, J. H. NATLAND, ET AL.

Pelagic

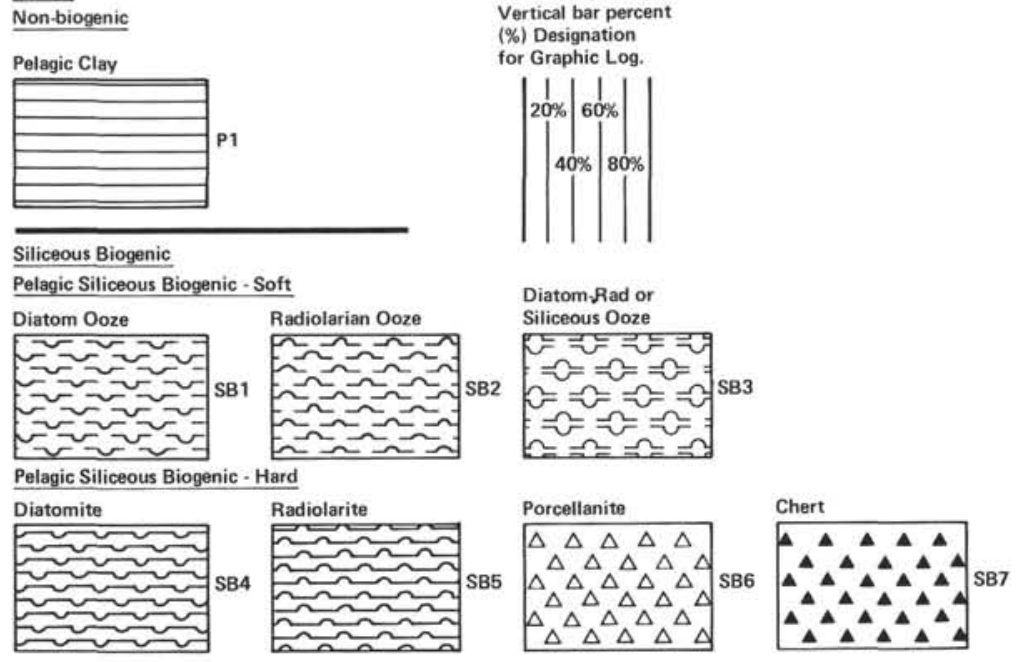

Transitional Siliceous Terrigenous Sediments
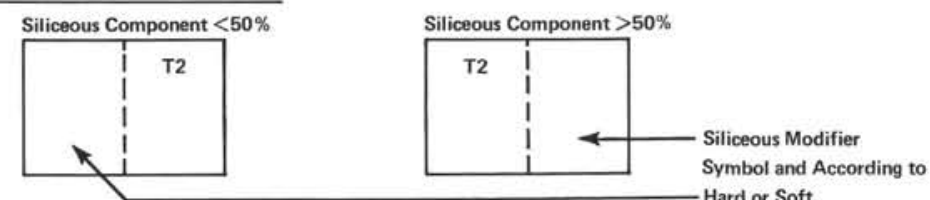

Hard or Soft.

Calcareous Biogenic

Pelagic Biogenic Calcareous - Soft

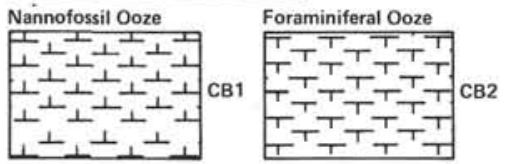

Pelagic Biogenic Calcareous - Firm

Nannofossil Chalk

Firm

Nanno-Foram or

Foram-Nanno Ooze Calcareous Ooze

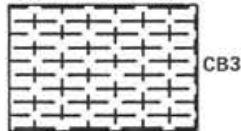

Calcareous Ooze

Nanno.Foram or

Foram-Nanno Chalk

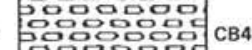

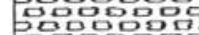

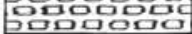

Foram-Nanno Chalk Calcareous Chalk
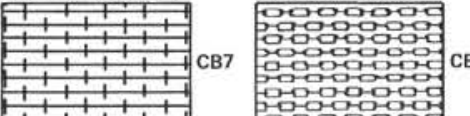

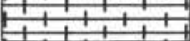

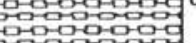

Pelagic Biogenic Calcareous - Hard

Limestone

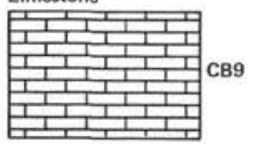

Terrigenous Sediments

Clay/Claystone

Qualifiers Letter Overprint (as per examples)

Zeolite A1 Glauconite A3 Siderite A4 (other may be designated)

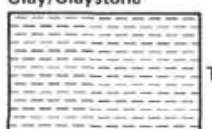

Shale (Fissile) Sandy Mud/Sandy Mudstone Silt/Siltstone
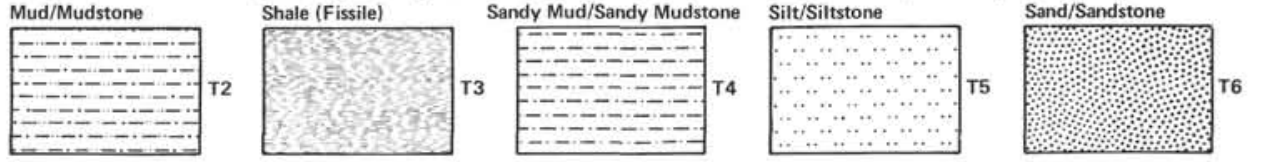

Silty Sand/ Pyroclastic

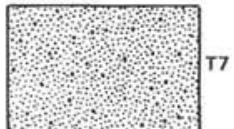

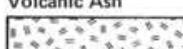
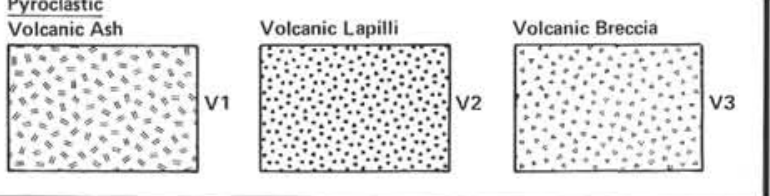

Basalt pebble (B)

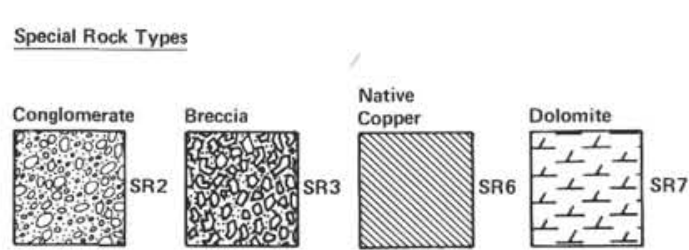

Concretions

Drawn Circle with Symbol (others may be designated)

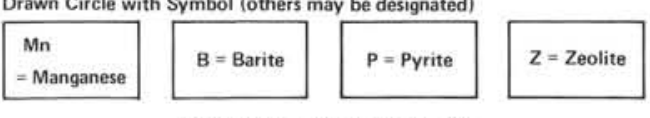

For special rock types not shown

For special rock types not shown

check with DSDP Staff

Figure 8. Graphic symbols corresponding to the lithologic visual core descriptions for sedimentary rocks and sediments. 
B. Boundary with siliceous biogenic sediments: $<30 \%$ identifiable siliceous remains.

C. Boundary with calcareous biogenous sediments: generally the sequence is one passing from pelagic clay through siliceous ooze to calcareous ooze, with one important exception: at the base of many oceanic sections, black, brown, or red clays occur directly on basalt, overlain by or grading up into calcareous sediments. Most of the basal clayey sediments are rich in iron, manganese, and metallic trace elements. For proper identification they require more elaborate geochemical work than is available on board. These sediments are placed in the "Special Rock" category, but care should be taken to distinguish them from ordinary pelagic clays.

II. Pelagic siliceous biogenic sediments. These sediments are distinguished from the previous category because they have more than $30 \%$ identifiable siliceous microfossils. They are distinguished from the following category by a $\mathrm{CaCO}_{3}$ content of less than $30 \%$. There are two classes: pelagic biogenic siliceous sediments (containing $<30 \%$ silt and clay, and transitional biogenic siliceous sediments (containing $>30 \%$ silt and clay and $>10 \%$ diatoms).

A. Pelagic biogenic siliceous sediments

1. Soft: siliceous ooze (radiolarian ooze, diatom ooze, depending on dominant component)

2. Hard: radiolarite, porcellanite, diatomite, chert

a) Qualifiers

(1) Radiolarians dominant: radiolarian ooze or radiolarite

(2) Diatoms dominant: diatom ooze or diatomite

(3) Where uncertain: siliceous (biogenic) ooze, or chert or porcellanite, when containing $>10 \% \mathrm{CaCO}_{3}$, qualifiers are as follows

(a) Indeterminate carbonate: calcareous... or,

(b) Nannofossils only: nannofossil...

(c) Foraminifers only: foraminifer...

(d) Nannofossil-foraminifer: depending on dominant component

(e) Foraminiferal-nannofossil: depending on dominant component

B. Transitional biogenic siliceous sediments

1. Diatoms $<50 \%$-diatomaceous mud: soft; diatomaceous mudstone: hard

2. Diatoms $>50 \%$-muddy diatom ooze: soft; muddy diatomite: hard

3. Radiolarian equivalents in this category are rare and can be specifically described.
III. Pelagic biogenic calcareous sediments. These are distinguished from the previous categories by a $\mathrm{CaCO}_{3}$ content in excess of $30 \%$. There are two classes: pelagic biogenic calcareous sediments (containing less than $30 \%$ silt and clay); and transitional biogenic calcareous sediments (containing more than $30 \%$ silt and clay). Calcareous sediments containing more than 10-20\% identifiable siliceous fossils carry the qualifier radiolarian, diatomaceous, or siliceous depending on the quality of the identification, for example, radiolarian-foraminifer ooze. Sediments containing $10-30 \% \mathrm{CaCO}_{3}$ fall in other classes where they are denoted with the adjective "calcareous." Less than $10 \% \mathrm{CaCO}_{3}$ is ignored.

A. Pelagic biogenic calcareous sediments

1. Hardness

a) Soft: calcareous ooze

b) Firm: chalk

c) Hard: indurated chalk

d) Cemented rocks: limestone

2. Compositional qualifiers: <, -; principal components are: nannofossils and foraminifers. One or two qualifiers may be used, for example:

\begin{tabular}{cl}
$\begin{array}{c}\text { Foraminifers } \\
(\%)\end{array}$ & \multicolumn{1}{c}{ Name } \\
\hline$<10$ & Nannofossil ooze, chalk, limestone \\
$10-25$ & Foraminiferal-nannofossil ooze \\
$25-50$ & Nannofossil-foraminifer ooze \\
$>50$ & Foraminifer ooze \\
\hline
\end{tabular}

B. Transitional biogenic calcareous sediments

1. $\mathrm{CaCO}_{3}=30-60 \%$ : marly calcareous pelagic sediments

a) Soft: marly calcareous (or nannofossil, foraminifer, etc.) ooze

b) Firm: marly chalk

c) Hard: marly limestone

2. $\mathrm{CaCO}_{3}>60 \%$ : calcareous pelagic sediments

a) Soft: calcareous (or nannofossil, foraminifer, etc.) ooze

b) Firm: chalk

c) Hard: limestone

IV. Terrigenous sediments

A. Sediments falling in this portion of the classification scheme are subdivided into textural groups on the basis of the relative proportions of three grain-size constituents, that is, clay, silt, and sand. Rocks coarser than sand size are treated as "Special Rock Types." The size limits for these constituents are those defined by Wentworth (1922) (Fig. 9). Five major textural groups are recognized on the triangular diagram shown in Figure 10. These groups are defined according to the abundance of clay $(>90 \%, 90-10 \%,<10 \%)$ and the ratio of sand to silt $(>1$ or $<1)$. Medi- 


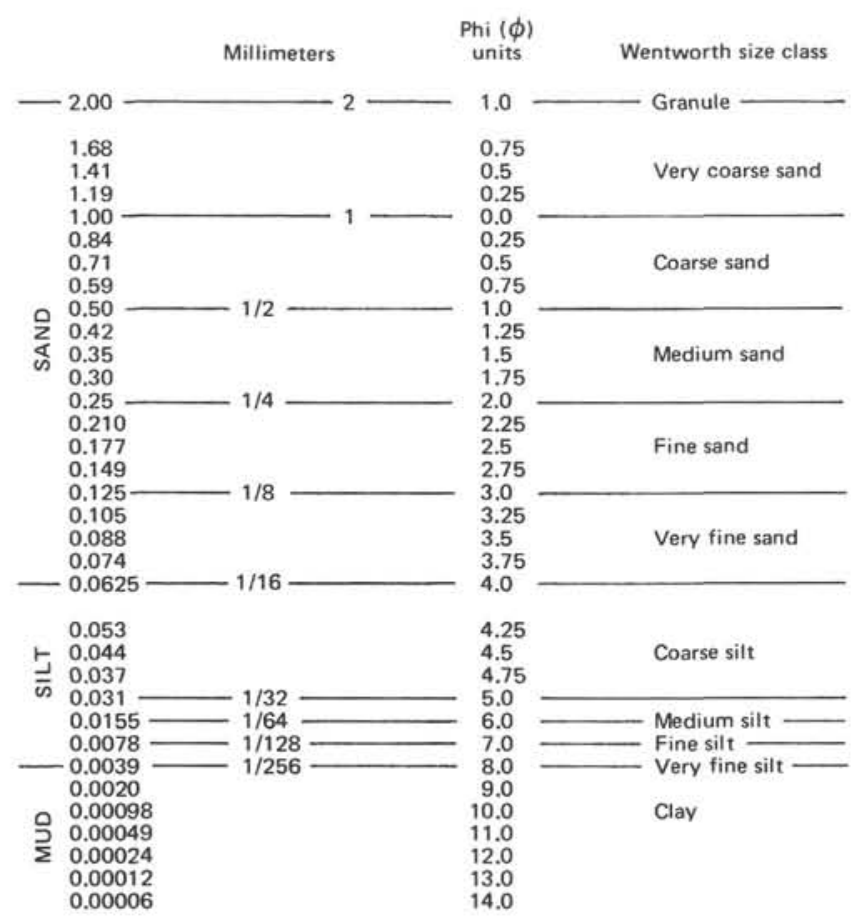

Figure 9. Grade scales for terrigenous sediments.

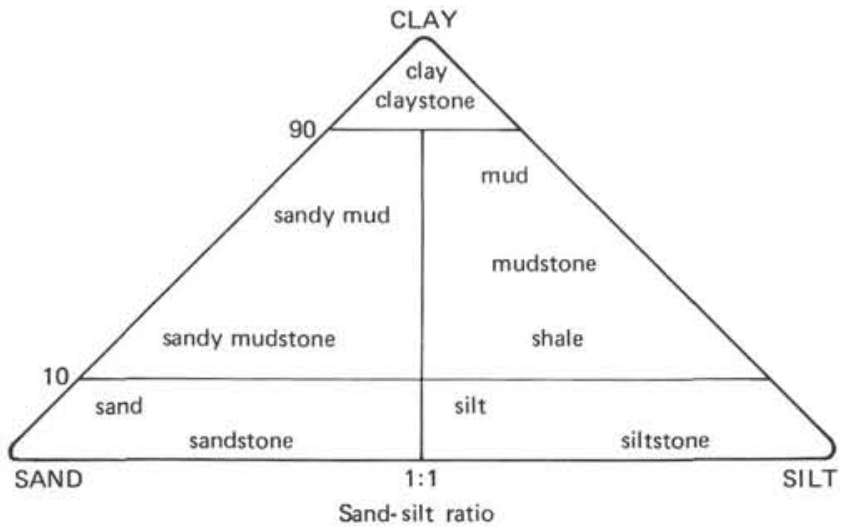

Figure 10. Class boundaries for terrigenous sediments.

um-, coarse-, or very coarse-grained sands and sandstones are categorized according to their median grain size.

1. Qualifiers. In this group numerous qualifiers are possible, usually based on minor constituents, for example, glauconitic, pyritic, feldspathic. In the sand and sandstone category, conventional divisions such as arkose, graywacke, and so on are, of course, acceptable, providing the scheme is properly identified. Clays, muds, silts, and sands containing $10-30 \% \mathrm{CaCO}_{3}$ are called calcareous.

B. Volcanogenic sediments. Pyroclastic rocks are described according to the textural and compositional scheme of Wentworth and Williams (1932).
1. Textural groups are:
a) Volcanic breccia $>32 \mathrm{~mm}$
b) Volcanic lapilli $<32 \mathrm{~mm}$
c) Volcanic ash (tuff, indurated) $<4 \mathrm{~mm}$

2. Compositionally, these pyroclastic rocks are described as vitric (glass), crystal, or lithic.

C. Clastic sediments of volcanic provenance are described in the same fashion as the terrigenous sediments, noting the dominant composition of the volcanic grains where possible.

V. Special rock types. The definition and nomenclature of sediment and rock types not included in the system just described are left to the discretion of shipboard scientists with the recommendation that they adhere as closely as is practical to conventional terminology. In this category fall such rocks as: intrusive and extrusive igneous rocks; evaporites, halite, anhydrite, gypsum (as a rock), and so on; shallow-water limestone (biostromal, biohermal, coquina, oolite, etc.); dolomite; gravels, conglomerates, breccias; metalliferous brown clays; concretions, barite, iron-manganese, phosphorite, pyrite, and so on; Coal, asphalt, and so on; and many others. The mandatory graphic lithology column should be completed by shipboard staff with appropriate symbols for intervals containing special rock types. It is imperative that symbols and rock nomenclatures by properly defined and described by shipboard staff.

\section{Zonation Schemes}

Nannofossils. The zonation of Okada and Bukry (1980) is utilized for Miocene and Pliocene sediments cored during Leg 78A. This zonation is not useful for the Pleistocene because of variations in the genus Gephyrocapsa. Therefore, the zonation of Gartner (1977) is adopted for the Pleistocene. However, his Helicopontosphaera sellii Zone and small Gephyrocapsa are not recognized at these sites, because $H$. sellii has a sporadic occurrence and the abundance of the small Gephyrocapsa is controlled by dissolution. One problem in adopting both zonations is that they both use Cyclococcolithina macintyrei for zonal names, although the generic name is different. The criteria of Verbeek (1977), Perch-Nielsen (1979), and Sissingh (1977) are used to zone the small amount of Campanian and Maestrichtian sediments recovered at Site 543 .

Planktonic foraminifers. The zonation proposed by Banner and Blow (1965) and refined by Blow (1969) is used. In the Pliocene, the zonal scheme established by Berggren (1973) from the Atlantic is used, and when possible the section is also assigned to the appropriate "N" zone of Blow.

Radiolarians. The radiolarian zones used are the chronozones defined by Riedel and Sanfilippo (1978), with the Thyrsocyrtis bromia Zone emended by Maurrasse and Glass (1976) and Saunders et al. (in press). 


\section{Basement Description Conventions}

\section{Core Forms}

Initial core description forms for igneous and metamorphic rocks are not the same as those used for sediments. The sediment barrel sheets are substantially those published in previous Initial Reports. Igneous rock representation on barrel sheets is too compressed to provide adequate information for potential sampling. Consequently, Visual Core Description forms, modified from those used on board ship, are used for more complete graphic representation. All shipboard data per $1.5-\mathrm{m}$ section of core are listed on the modified forms as well as summary hand-specimen and thin-section descriptions. The symbols and a number of format conventions for igneous rocks are presented on Figure 11.
Igneous and metamorphic rocks are split, using a rock saw with a diamond blade, into archive and working halves. The latter are described and sampled on board ship. On a typical igneous rock description form (Fig. 12), the left column is a visual representation of the working half using the symbols of Figure 11. Two closely spaced horizontal lines in this column indicate the location of styrofoam spacers taped between basalt pieces inside the liner. Each piece is numbered sequentially from the top of each section, beginning with the number 1 . Pieces are labeled on the rounded, not the sawed surface. Pieces that could be fitted together before splitting are given the same number, but are consecutively lettered, as $1 \mathrm{~A}$, $1 \mathrm{~B}, 1 \mathrm{C}$, and so on. Spacers are placed between pieces with different numbers, but not between those with different letters and the same number. In general, addition
Texture:

(used in graphic representation column)

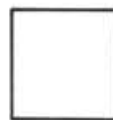

Aphyric basalt

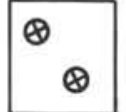

Variolitic basalt

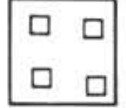

Porphyritic basalt Olivine and plagioclase phenocrysts

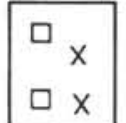

Olivine plagioclase and clinopyroxene

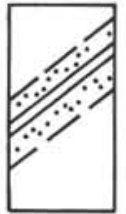

Vein with altered zone next to it

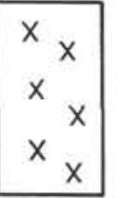

Gabbro

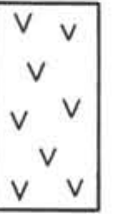

\section{Dolerite}

(diabase)

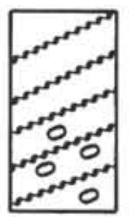

Serpentinite (shear orientation approximately as in core; augen shown toward bottom) phenocrysts

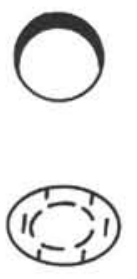

Glass on edge (rounded piece)

Weathered rind on rounded piece

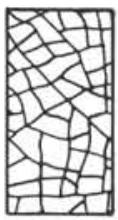

Fractures

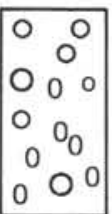

Vesicles (approx. size)

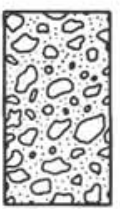

Breccia

(as graphic as possible)

Local occurrences (indicate to right of alteration column):

$+=$ altered olivine phenocryst

$0=$ quartz crystals

$C=$ calcite veins

= clay-filled vesicles

₹ $=$ calcite-filled vesicles

WDNT = baked mudstone-chert selvage

$R=$ red clays and/or iron hydroxides

$\mathrm{G}=$ green clays

$\mathrm{B}=$ blue green clays

P = pyrite or other metallic sulfides

\section{Weathering: Alteration}

(used in alteration column)
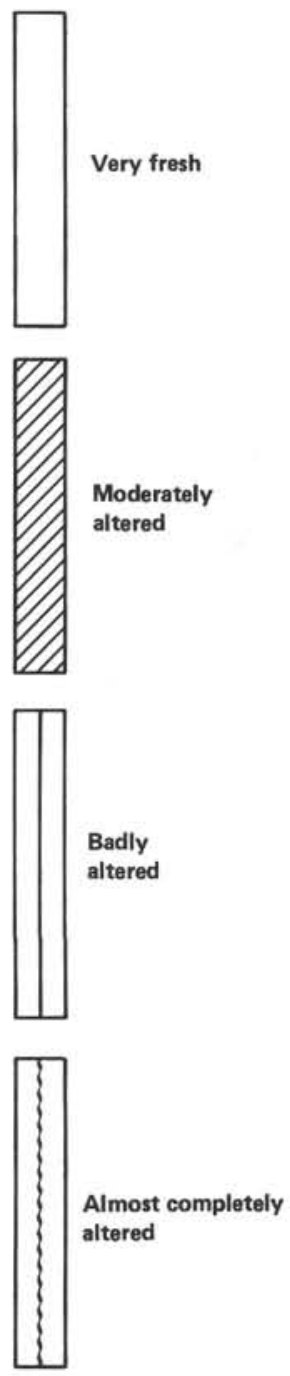

Figure 11. List of symbols for igneous rock description forms. 
J. C. MOORE, B. BIJU-DUVAL, J. H. NATLAND, ET AL.

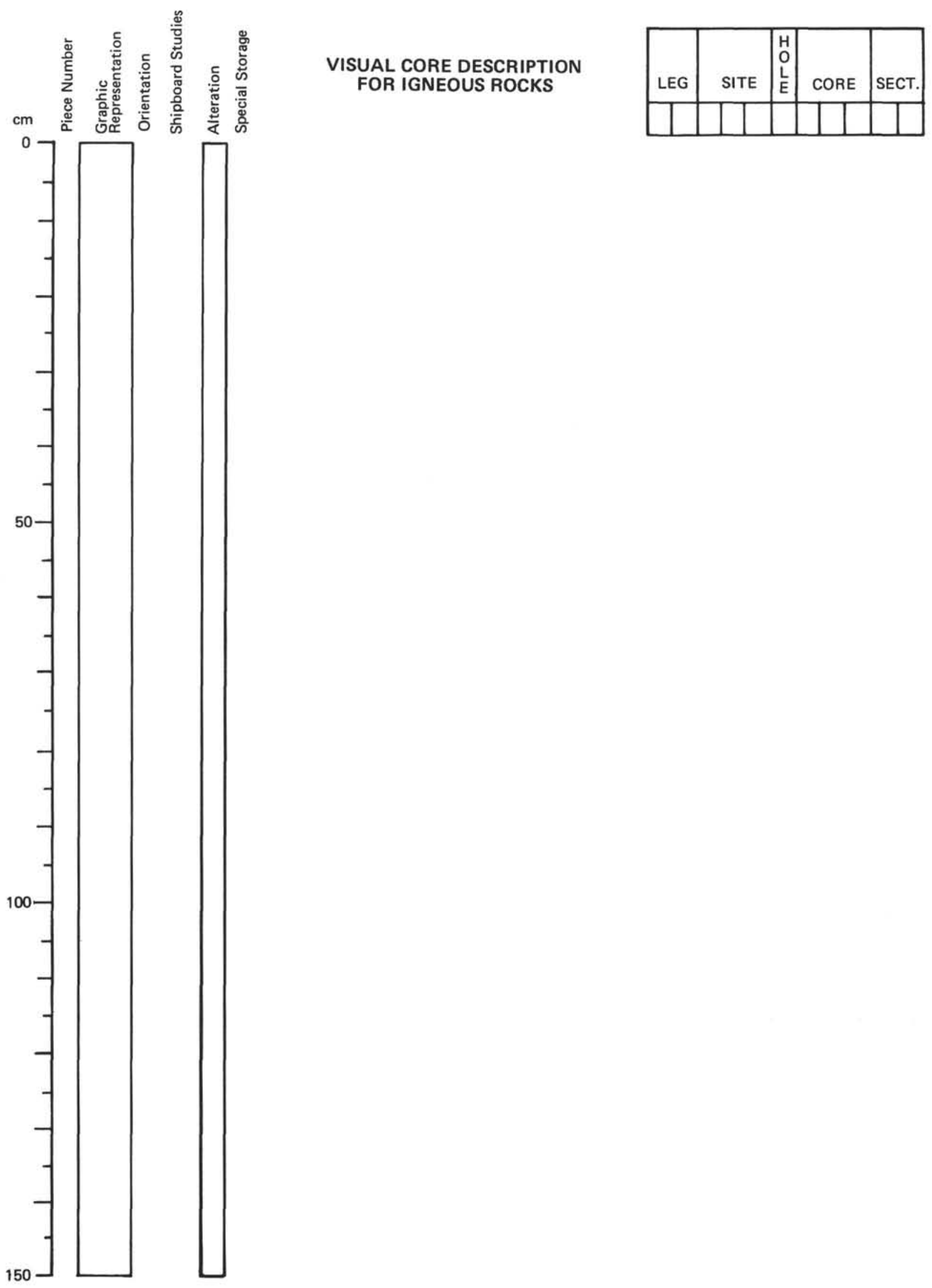

Figure 12. Typical igneous rock description form. 
of spacers represents a drilling gap (no recovery). However, in cores where recovery is high, it is impractical to use spacers. In these cases, drilling gaps are indicated only by a change in numbers. All pieces have orientation arrows pointing to the top of the section, both on archive and working halves, provided the original unsplit piece was cylindrical in the liner and of greater length than the diameter of the liner. Special procedures are used to ensure that orientation is preserved through every step of the sawing and labeling process. All pieces suitable for sampling requiring knowledge of top from bottom are indicated by upward-pointing arrows to the left of the piece numbers on the description forms. Because the pieces are rotated during drilling, it is not possible to sample for declination studies.

Samples are taken for various measurements on board ship. The type of measurement and approximate location are indicated in the column headed Sample using the following notation: $\mathrm{X}=\mathrm{X}$-ray fluorescence analysis; $\mathbf{M}=$ magnetics measurements; $\mathrm{S}=$ sonic velocity measurements; $\mathrm{T}=$ thin section; $\mathrm{D}=$ density measurements; and $\mathrm{P}=$ porosity measurements.

Up to seven such visual representations can be included on a single igneous rock core description sheet (see Site 543 descriptions), which includes a summary core description and petrographic, and analytical data.

\section{Igneous Rock Classification}

Igneous rocks are classified mainly on the basis of mineralogy and texture. Thin-section work in general adds little new information to the hand-specimen classification.

Basalts are termed aphyric, sparsely phyric, moderately phyric, or phyric, depending on the proportion of phenocrysts visible with the binocular microscope $(\sim \times 12)$. The basalts are called aphyric if phenocrysts are absent. (For practical purposes, if one piece of basalt is found with a phenocryst or two in a section where all other pieces lack phenocrysts, and no other criteria such as grain size or texture distinguish this basalt from the others, then it is described as aphyric.) A note on the rare phenocrysts is included in the general description, however. This approach enables us to restrict the number of lithologic units to those that appear to be clearly distinct.

Sparsely phyric basalts are those with $1-2 \%$ phenocrysts present in almost every piece of a given core or section. Clearly contiguous pieces without phenocrysts are included in this category, again with the lack of phenocrysts noted in the general description.

Moderately phyric basalts contain $2-10 \%$ phenocrysts. Aphyric basalts within a group of moderately phyric basalts are separately termed aphyric basalts.

Phyric basalts contain more than $10 \%$ phenocrysts. No separate designation is made for basalts with more than $20 \%$ phenocrysts; the proportion indicated in the core forms should be sufficient to guide the reader.

The basalts are further classified by phenocryst type, preceding the terms phyric, sparsely phyric, and so on. For example, a plagioclase-olivine moderately phyric ba- salt contains $2-10 \%$ phenocrysts, most of them plagioclase, but with some olivine.

Other rock types that are less commonly recovered, such as gabbro, serpentinite, andesites, granite, or metamorphic rocks, are classified using standard references such as Williams et al. (1954) or Moorhouse (1959).

\section{REFERENCES}

Banner, F. T., and Blow, W. H., 1965. Progress in the planktonic foraminiferal biostratigraphy of the Neogene. Nature, 208:1164-1166.

Beck, R. H., 1972. The oceans, the new frontier in exploration. Aust. Pet. Explor. Assoc. J., 12:1-21.

Berggren, W. A., 1973. The Pliocene time scale: calibration of planktonic foraminiferal and calcareous nannoplankton zones. Nature, 243:391-397.

Biju-Duval, B., Le Quellec, P., Mascle, A., Renard, V., and Valery, P., 1982. Multibeam bathymetric survey and high-resolution seismic investigations on the Barbados Ridge complex (eastern Caribbean): a key to the knowledge and interpretation of an accretionary wedge. Tectonophysics, 86:275-304.

Biju-Duval, B., Mascle, A., Montadert, L., and Wannesson, J., 1978. Seismic investigations in Colombia, Venezuela, and Grenada Basins, and on the Barbados Ridge for future IPOD drilling. Geol. Mijnbouw, 57:105-116.

Blow, W. H., 1969. Late middle Eocene to recent planktonic biostratigraphy. Proc. Ist Internat. Conf. Planktonic Microfossils, Geneva, 1967, 1:199-422.

Boyce, R. E., 1976. Definitions and laboratory techniques of compressional sound velocity parameters, wet-water content, wet-bulk density and porosity parameters by gravimetric and gamma-ray attenuation techniques. In Schlanger, S., Jackson, E. D., et al., Init. Repts. DSDP, 33: Washington (U.S. Govt. Printing Office), 931-957.

Chase, R. L., and Bunce, E. T., 1969. Underthrusting of the eastern margin of the Antilles by the floor of the western North Atlantic Ocean, and the origin of the Barbados Ridge. J. Geophys. Res., 74:1413-1420.

Davies, S. N., 1971. Barbados: a major submarine gravity slide. Geol. Soc. Am. Bull., 82:2593-2602.

Gartner, S., 1977. Calcareous nannofossil biostratigraphy and revised zonation of the Pleistocene. Mar. Micropaleontol., 2:1-25.

Hussong, D. M., Uyeda, S., et al., 1982. Init. Repts. DSDP, 60: Washington (U.S. Govt. Printing Office).

Karig, D. E., 1974. Evolution of the western Pacific. Ann. Rev. Earth Planet. Sci., 2:51-76.

Karig, D. E., and Sharman, G. F., III, 1975. Subduction and accretion in trenches. Geol. Soc. Am. Bull., 86:f377-389.

Marlow, M. S., Garrison, L. E., Martin, R. E. G., Trumball, J. U. A., and Cooper, A. K., 1974. Tectonic transition zone in the northeastern Caribbean. J. Res. U.S. Geol. Surv., 2:289-302.

Martin-Kay, P. H. A., 1969. A summary of the geology of the Lesser Antilles. Overseas Geol. Miner. Resour. G. B., 10:172-206.

Mascle, A., Lajat, D., and Nely, G., in press. Sediment deformation linked to subduction and to argillokinesis in the southern Barbados Ridge from multichannel seismic surveys. Trans. 4th LatinAm. Geol. Congr.

Mattinson, J. M., Fink, L. K., Jr., and Hopson, C. A., 1979. La Desirade Island ophiolite: age, isotopic and tectonic relationships. Eos, 60:969.

Maurrasse, F., and Glass, B., 1976. Radiolarian stratigraphy and North American microtectites in Caribbean RC9-58: implications concerning late Eocene radiolarian chronology and the age of the Eocene/Oligocene boundary. In Publication de la VII Conference Geologique des Caraibes du 30 Juin au 12 Juillet 1974 (VII Conference Geologique des Caraibes, Cayenne, Départment Français de la Guyane), pp. 205-212.

Minster, J. B., and Jordan, T. H., 1978. Present-day plate motions. $J$. Geophys. Res., 83:5331-5354.

Moberly, R., Jr., and Heath, G. R., 1971. Carbonate sedimentary rocks from the western Pacific: Leg 7, Deep Sea Drilling Project. In Winterer, E. L., Riedel, W. R., et al., Init. Repts. DSDP, 7: Washington (U..S Govt. Printing Office), 977-985.

Moore, J. C., 1975. Selective subduction. Geology, 3:530-532. 
Moorhouse, W. W., 1959. The Study of Rocks in Thin Section: New York (Harper and Row).

Okada, H., and Bukry, D., 1980. Supplementary modification and introduction of code numbers to the low-latitude coccolith biostratigraphic zonation (Bukry, 1973, 1975). Mar. Micropaleontol., 5: 321-325.

Perch-Nielsen, K., 1979. Calcareous nannofossils from the Cretaceous between the North Sea and the Mediterranean. Aspekte Kreide Europas, IUGS, Ser. A, 6:223-272.

Peter, G., and Westbrook, G. K., 1976. Tectonics of the southwestern North Atlantic and Barbados Ridge complex. Am. Assoc. Pet. Geol. Bull., 60:1078-1106.

Pudsey, C. J., and Reading, H. G., 1982. Sedimentology and structure of the Scotland Group, Barbados. In Leggett, J. K. (Ed.), TrenchForearc geology: Sedimentation and Tectonics on Modern and Ancient Active Plate Margins, Geol. Soc. London Spec. Publ., 291-308.

Riedel, W. R., and Sanfilippo, A., 1978. Stratigraphy of tropical Cenozoic radiolarians. Micropaleontology, 24:61-96.

Saunders, J. B., 1965. Field trip guide, Barbados. 4th Caribbean Geol. Congr., Trinidad, pp. 443-449.

1980. The development of the Caribbean with special reference to the southern margin and the Venezuela Basin. In Geology of the Alpine Chains Born of Tethys, Proc. Int. Geol. Congr. Bur. Rech. Geol. Min., pp. 237-243.

Saunders, J. B., Bernoulli, D., Müller Merz, E., Oberhansli, H., PerchNielsen, K., Riedel, W. R., and Sanfilippo, A. B., in press. Stratigraphy of the late middle Eocene to early Oligocene in the Bath Cliff section, Barbados, West Indies. Micropaleontology.

Scholl, D. W., and Marlow, M. S., 1974. Sedimentary sequences in modern Pacific trenches and the deformed circum-Pacific eugeosyncline. In Dott, R. H., and Shaver, R. H. (Eds.), Modern and Ancient Geosynclinal Sedimentation, Soc. Econ. Paleontol. Mineral. Spec. Publ., 19:193-211.

Scholl, D. W., von Huene, R., Vallier, T. L., and Howell, D. G., 1980. Sedimentary masses and concepts about tectonic processes at underthrust ocean margins. Geology, 8:564-568.

Seely, D. R., Vail, P. R., and Walton, G. G., 1974. Trench slope model. In Burk, C. A., and Drake, C. L. (Eds.), The Geology of Continental Margins: New York (Springer-Verlag), pp. 249-260.
Sissingh, W., 1977. Biostratigraphy of Cretaceous calcareous nannoplankton. Geol. Mijnbouw, 56:37-65.

Speed, R. C., in press. Geology of Barbados: implication for an accretionary origin. Int. Geol. Congr. Paris.

Tomblin, J. F., 1975. The Lesser Antilles and Aves Ridge. In Nairn, A. E. M., and Stehli, F. (Eds.), The Ocean Basins and Margins, 3: the North Atlantic: New York (Plenum), 1-64.

Verbeek, J. W., 1977. Calcareous nannoplankton biostratigraphy of middle and Upper Cretaceous deposits in Tunisia, southern Spain, and France. Utrecht Micropaleontol. Bull., 16:157.

von Huene, R., Aubouin, J., et al., 1980. Leg 67, DSDP: Mid-America transect off Guatemala. Geol. Soc. Am. Bull., 91:421-432.

Watkins, J. S., McMillen, K. J., Bachman, S. B., Shipley, T. S., Moore, J. C., and Angevine, C., 1982. Tectonic synthesis, Leg 66: transect and vicinity. In Watkins, J. S., Moore, J. C., et al., Init. Repts. DSDP, 66: Washington (U.S. Govt. Printing Office), 837-849.

Watkins, J. S., Moore, J. C., et al., 1982. Init. Repts. DSDP, 66: Washington (U.S. Govt. Printing Office).

Wentworth, C. K., 1922. A scale of grade and class terms for clastic sediments. J. Geol., 30:377-392.

Wentworth, C. K., and Williams, H., 1932. The classification and terminology of the pyroclastic rocks. Bull. Nat. Res. Counc., 89: 19-53.

Westbrook, G. K., 1975. The structure of the crust and upper mantle in the region of Barbados and the Lesser Antilles. Geophys. J. R. Astron. Soc., 43:201-242.

1982. The Barbados Ridge complex: tectonics of a mature forearc system. In Leggett, J. K. (Ed.), Trench-Forearc Sedimentation and Tectonics on Modern and Ancient Active Plate Margins, Geol. Soc. London Spec. Publ., v 275-290.

Westbrook, G. K., Bott, M. P. H., and Peacock, J. H., 1973. Lesser Antilles subduction zone in the vicinity of Barbados. Nature Phys. Sci., 244:118-120.

Williams, H., Turner, F. J., and Gilbert, C. M., 1954. Petrography: an Introduction to the Study of Rocks in Thin Section: San Francisco (W. H. Freeman and Co.).

Date of Initial Receipt: September 22, 1983 Date of Acceptance: October 3, 1983 